16. Scheff H., Sprague M., McGreevy-Nichols, S. (2010). Exploring dance forms and styles : a guide to concert, world, social, and historical dance. Champaign, IL: Human Kinetics.

17. Taraborrelli, J. R. (2010). Michael Jackson : the magic, the madness, the whole story, 19582009. 1st Grand Central Publishing rev. and updated. New York: Grand Central Pub.

18. Van den Akker R., Gibbons A., Vermeulen T. (2017). Metamodernism : historicity, affect and depth after post-modernism. London; New York: Rowman \& Littlefield International. (Radical cultural studies).

19. Waldenfels B. Leibhafiger Tanz - im Blick der Phänomenologie. Goethe-Institut e. V., Internet-Redaktion [online]. Available at: <http://www.goethe.de/kue/tut/deindex.htm> [Accessed 02 July 2017].

УДК 130.2:124.4

ORCID: 0000-0002-1350-5505

Наталія Кисла,

здобувач кафедри культурології Національної музичної академії України ім. П. І. Чайковського, солістка Національної опери України, вул. Володимирська, 50, Київ, 01030, Украӥна

Nataliia Kysla, Applicant at the Department of Cultural Studies, Ukrainian National Tchaikovsky academy of music, Soloist of the National Opera of Ukraine, 50 Volodymyrska St., Kyiv 01030, Ukraine

\title{
ПАРАМЕТРИ ХУДОЖНЬОЇ КУЛЬТУРИ НА МЕЖІ КЛАСИЧНОГО, НЕКЛАСИЧНОГО ТА ПОСТНЕКЛАСИЧНОГО ОБРАЗУ СВІТУ
}

У статті з позицій нових наукових досліджень розглядаються параметри художньої культури та напрями іiі трансформації. Виділено провідні характеристики образу світу в різних культурологічних параметрах, за якими відбувається формування стильових систем у проекції на різні види мистецтва. Розкрито особливості художньої культури на різних етапах бачення образу світу в класичну, некласичну та постнекласичну культурні епохи.

Ключові слова: художня культура, художньо-естетичні форми, образ світу, класична, некласична та постнекласична культурні епохи.

Parameters of art-culture on the facets of the classical, nonclassical and post-nonclassical image of the world. From the standpoint of new scientific studies, the parameters of artistic culture and directions of its transformation are considered. The leading characteristics of the image of the world in various cultural parameters, in which the formation of stylistic systems 
in the projection into different types of art takes place, are singled out. The features of artistic culture at different stages are revealed, the vision of the image of the world in the classical, non-classical and post-classical cultural epochs.

Key words: artistic culture; artistic and aesthetic forms; the image of the world; classical, non-classical and post-classical cultural epochs.

\section{Параметры художественной культуры на границе} классического, неклассического и постнеклассического образа мира. В статье с позиций новых научных исследований рассматриваются параметры художественной культуры и направления ее трансформации. Выделены ведущие характеристики образа мира в различных культурологических ипостасях, согласно которым происходит формирование стилевых систем в проекции на разные виды искусства. Раскрыты особенности художественной культуры на разных этапах и видение концепта «образ мира» в классическую, неклассическую и постнеклассическую культурные эпохи.

Ключевые слова: художественная культура, художественноэстетические формы, образ мира, классическая, неклассическая и постнеклассическая культурные эпохи.

Актуальність теми дослідження зумовлена відчутними змінами в еволюції сучасної картини світу. Трансформації культурного універсуму в нашу епоху актуалізують завдання пошуку векторів розв'язання комплексу взаємопов'язаних онтологічних, гносеологічних, культурологічних та інших проблем. Їх вирішення сприяє оновленню базових основ гуманітарних знань. Останнім часом за аналогією з моделлю типологізації науки здійснюється поділ культури на класичну, некласичну i постнекласичну на підставі різних критеріїв [4]. Це обумовлює додатковий ракурс актуальності теми, оскільки художня картина світу бере участь у трансляції й трансформації духовних цінностей у суспільстві, що продукуються, зокрема, за допомогою художньо-естетичних форм. Ця тема потребує загостреного просторового бачення темпоральності реалій культури, які реалізуються в певному суспільному просторі.

Новим аспектом розгляду такого простору слугують компаративні характеристики основних параметрів художньої культури класичного, некласичного та постнекласичного образу світу.

Mema - означити актуальні параметри та напрями трансформації образу світу в класичній, некласичній та постнекласичній культурах. Завдання cmammi багатоаспектні й полягають в інтеграції історикодинамічного, філософського та культурологічного ракурсів розгляду 
художніх параметрів; осмисленні засад осягнення культурних параметрів образу світу в класичній, некласичній та постнекласичній наукових парадигмах.

Методи дослідження. У статті використано загальнонаукову методологію (аналіз, синтез, індукцію, дедукцію, узагальнення); кроскультурний та системний методи аналізу; компаративний підхід, що надали можливість охарактеризувати актуальні художні параметри концепту «образ світу» в динаміці. Для розгляду напрямів його трансформації застосовано трансцендентальний, феноменологічний та діалектичний методи.

Виклад основного матеріалу. У сучасній науці поняття «класична культура» трактується в широкому й вузькому значеннях. У широкому розумінні - це вся пост-первісна культура Свразії, у вузькому - культура Античності і європейська міська культура, яка тією чи іншою мірою відтворює в своїх формах античні зразки. Характерною рисою такого типу культури є іï обумовленість владною ідеологією, пропагандою якої ця культура займається. «Це культура-ідеологія в найбільш ऑї чистому вигляді» [4]. Класична культура не обмежується мистецтвом й архітектурою, а включає в себе весь набір символічних форм соціальнопобутового, військово-політичного характеру. Гранично чіткий розподіл світу на добро i зло, гарне і погане, милостиве і гріховне, правильне i неправильне - головне, що відрізняє цю культуру. Основний тип свідомості тут логоцентричний, який, на думку К. Ясперса, виник у процесі культурної трансформації «вісьового часу» (IX-III ст. до н. е.) [6, с. 45]. Художні форми класичної культури, як правило, міметичні.

Друга половина XIX ст. суттєво трансформує сприйняття й інтерпретації світу в свідомості людей. Цей поворот у культурі пов'язаний з її некласичним періодом. У такому типі культури найбільшого розголосу набула ідея контекстуальної залежності будь-якої істини. Навіть простір і час $є$ продуктом вселенського контексту. Тому некласичною культурою були розроблені нові культурні форми, які прийшли на зміну класичним.

В останній третині XX ст. як наслідок іще одного науково-технічного перевороту виникає нова дистанційна система міжособистісної комунікації (маємо на увазі становленні Інтернету, масове користування індивідуальними комп'ютерами й розвиток соціальних мереж). Одночасно в науці відбулося становлення нової дослідницької парадигми, названої постнекласичною. Її автор - науковець В. Стьопін, якій розрізняє чотири «людиновимірні» історично динамічні системи 3 трансформованими гуманітарними цінностями [3, с. 619-640]. Це істотно вплинуло на культуру. 
У культурі це призвело до переходу від книжкової до екранної культури й розгорнуло процес соціального превалювання масової культури. «Хоча народження постнекласичної науки в основному пов'язується iз синергетикою, це нове розуміння істини виразилося найбільше в культурнофілософському перебігу постмодернізму, що дає нам підставу цей новий етап у розвитку культури назвати постнекласичною культурою, за аналогією з наукою», - стверджує А. Флієр [4].

Тлумаченню поняття «образ світу» присвячено велику кількість наукових розвідок (максимально повний їх перелік надано в статті А. Шубіної [5, с. 94-98]). Узагальнюючи характеристики, ми визначаємо образ світу як спосіб відтворення картини світу за допомогою художньообразної інтерпретації. Ми схиляємось до означення Р. Мусат: «Образ світу - абстрактна модель, сформована у сфері філософського пізнання світу як теоретичне узагальнення й систематизація принципів художнього мислення людини» [2, с. 117]. Водночас виникає тісний зв'язок із теорією мистецтва, так як він базується на основі особливостей художньоестетичного осмислення світу та безпосередньо здійснюється через художній образ. Якщо художній образ наочно відображає й описує навколишній світ у конкретних життєвих ситуаціях, то образ світу розкриває контексти виникнення художніх образів та принципи їх формування. До того ж часто дефініції категорій окремих видів мистецтва універсалізуються й стають пояснювальними принципами або інтерпретативними схемами культури як такої.

Найбільш характерні риси нової культури вже були описані в спеціальній літературі, отже ми зупинимося лише на принциповій відмінності постнекласичної культури від класичної й некласичної. Насамперед слід зазначити, що, якщо некласична культура відкидала форми класичної, але не заперечувала проти ії культурних змістів, то постнекласична, навпаки, цілком лояльна до форм, але відкидає культурні смисли минулого. До історичних культурних форм постнекласична культура ставиться з іронічним заступництвом, охоче використовуючи їх у своїх парадоксальних концептуальних конструкціях і вважаючи, що всі слова давно сказані, усі образи вже створені й завдання сучасної культури використовувати ї у різних інтерпретаціях. А ось культурні смисли обумовлені контекстами, які з плином історії змінюються, і сьогоднішні звернення до стародавніх контекстів щонайменше неактуальні. Потрібно створювати сучасні контексти, поміщаючи в них класичні сюжети. Найбільш відомий приклад такого підходу містить кінофільм База Лурмана «Ромео + Джульєтта» 3 Леонардо Ді Капріо та Клер Дейнс, дію 
якого перенесено в сучасну Америку. Дослідження науковців із сучасної режисерської інтерпретації класичних опер також добре відомі. Можна зробити висновок: якщо класична культура була стурбована створенням нових форм, то некласична займається здебільшого реінтерпретацією старих форм. Але нові тенденції вже проявилися та закріплюються. I цей процес описує параболу від соціального аспекту до культурного (перехід від книжкової до екранної культури та, взагалі, зростаючого відчуження від класичної культури).

Важливо побачити тенденцію позбавлення часової означеності та пошуку можливостей культури уникнути часу, бажання знайти образ позачасовий острів буття. Це один із цікавих напрямів образних метаморфоз та втечі людини від страшенного молоху - хроносу. В уявленнях християн після Страшного суду часу вже не буде. Саме так і в культурі постнекласичного світу перманентно «відбувається» Страшний суд, після якого часовий параметр зникає. Важливо прослідкувати еволюцію формотворчих стратегій, топологічних схем або концептів, які залежать від трансформації уявлень про час як формотворчі темпоральності мистецького твору.

Стиль модерн провокував творчість як субституцію абсолюту, деміургом і креатором була певна людина або вітальна сила. Імпульсом іще не була воля до влади. Мистецтво сповнювалося волею до життя. Саме так можна було означити стильовий напрям модерну, і це призводило до продукування рослинних, орнаментальних, лінеарних пружних конструкцій. Конструкції в архітектурі або в дизайні виносилися на поверхню. У дизайні одягу вони були пов'язані 3 демонстративним нехтуванням попередньою традицією царювання кринолінів, ліфів, що надавало можливість «волевиявлення» лінії людського тіла в одязі.

Проаналізуємо книжкову графіку Ерте, який створив свій власний напрям видовища в книжному світі й побачимо, що це надзвичайно цікавий стиліст. Його моделі й зараз приваблюють своїм конструктивізмом і своєю витонченою лінеарністю. Лише Г. Клімт може порівнятись із ним у грі такого орнаментально-візерункового світу. Питання індивідуальної топології їх видовища мали просторові інваріанти, які зі стилю модерн увійшли в простір авангарду й постмодерну. Вкажемо на персональну означеність простору артистизмом, де панує надмірна зображальність й орнаментальність, барвистість, більше того - теургізм і своєрідний месіанізм, який без будь-яких змін увійшов в інші наступні спроби стилеутворення XXI століття. Сучасне видовище іншою мовою та в інших контекстах намагалося трансформувати ейдетику того посткласичного 
простору, який відкрив світу модерн. Але авангард загострив елементаризм і вивів на перший план прості та ясні конструктивні ознаки. Це своєрідні платонові тіла, які на перший погляд наче «говорять» про просте, а насправді створюють іще одну додаткову складність.

Не можна стверджувати, що композиція авангардного простору $є$ гармонійна єдність і впорядкований склад цих елементів. Навпаки, принципом композиції є єднання нез'єднаного: тих інтуїцій, які лише маркуються та виносяться назовні як елемент. Виникає вигляд простої форми, яка всередині є цілком багатошаровою, де внутрішній простір перенасичений символічними ознаками. Цей символізм цілком топологічно є тотожним реаліям стилю модерн. Тобто художній образ авангардного світу розгортається як дія, як акт, як вчинок. Це своєрідна маніфестація та виголошення позиції як жест волевиявлення людини перед світом. I такий художній образ світу - перифраз модерних настанов (сплав теургізму й орнаменталізму).

Якщо ми подивимось на роботи Габріель Шанель і створений нею образ маленької чорної сукні та порівняємо з трактовкою чорного кольору в роботах Малевича та Пікассо, то побачимо певну індивідуальну творчу трансформацію. Символіка чорного тут $є$ різною. В авторському варіанті Габріель Шанель присутній фрейдистський архетип, бо майстриня спромоглася чорним накрити біле. Це католицький мотив, який вона винесла з того притулку, в якому жила дитиною. У Малевича, навпаки, біле вкриває чорне й чорний квадрат начебто сходить 3 полотна й випромінює тріщинками те світло, яке ховається за цим чорним. Чорне у Пікассо - це гнучка драматична лінія його робіт, де виникає глибинне тло, на якому рухаються динамічні трикутники складних антропоморфних форм. Отже, складно утворюється драматургія видива, але вона топологічно інваріантна. Інваріантна тому, як чорне і біле як аналог темряви і світла, як аналог добра і зла, в контексті різних експлікацій відтворюють достатньо прості і ясні інтуїції. Це некласичний тип образу світу, який в умовах авангарду синтезує в собі те, що було вже в модерні.

Можна сказати, що конструкції, які несуть в собі первинні архетипи простоти й просторові настанови розчленування верху i низу, геометризацію, співмірні настановам світогляду того століття, є топологічно інваріантними. Саме тому бажаний образ людини у світі це - людина на тлі неба, як, наприклад, у М. Шагала. Так, людина на тлі просторової далечини є еквівалентною для культури постнекласичного століття.

Роботи блакитного й рожевого періодів П. Пікассо є в певному сенсі буквально модерними його роботами. У стилістиці художника ще немає 
деструкції тіла, але присутня деяка особливість класичного впорядкування та аранжування простору: є певні куліси, є орнаменталізм. Серія його робіт портретного жанру та сюжетних картин, де ми бачимо комедіантів, акторів, сімейство бродячих акробатів, дівчину на кулі - це все рефрен стилю модерн і рефрен досить своєрідний. Людина закинута в простір, в якому чітко позначено горизонт. Цей простір нагадує куліси графічних робіт Франсіско Гойя, i в цьому достатньо плоскому й водночас глибинному формотворчому видиві розгортається видовище відношення людини до світу. Люди й дивляться, і не дивляться одне на одного. Вони більш замріяні, вони більше маніфестують свою людяність як самотність, як якусь пригніченість. Як, наприклад, жебраки на березі моря. Це майже біблійний сюжет, де море людське, як людська доля, обіймає, омиває величезний простір людського буття. Цих інваріантів не позбутись у XXI столітті. Спочатку їх винесло на поверхню творчості, а потім із часом трансформувало: сховало, розпалило, зламало в того ж Пікассо в його наступних роботах. Якщо ми дивимось, наприклад, на його «Арлекіна», то помічаємо, що це вже суто орнаментальна модерністська композиція, що несе ідею тої ж самотності, ту ж далечину розподілу простору. Саме там $є$ умовний горизонт як образ лінії горизонту, яку знаходить людина. У компліментарному русі ми бачимо якусь гойдалку, яка сприймається як символ динамічного незрівноваженого існування людини у світі. Майже всі роботи Пікассо кубістичного періоду несуть той же драматургічний поштовх, подібний внутрішній незаспокоєності дівчини на кулі, пошук гармонії.

Всесвіт як катастрофа, як вибух - це вже складові постмодерного ряду. Перманентне пересування від однієї деструкції культури до іншої не в змозі подолати глибинні настроювання механізмів на ідентичності людини, але зможе винайти їхнє образне втілення у видовищі. Людина звикає до всіх трансформацій і радикалізм еклектики сучасної культури постнекласичного світу сприймається як безмежний своєрідний процес варіювання вибухової катастрофи.

Інсталяція Іссей Міяке більшою мірою є постмодерним видовищем. Його вирішення надано у своєрідному аспекті. Так, коли на вал намотані силуети людини, це, звичайно, видовище й видовище жахливе. Пласка людина (та іiї силует), ціла тканина з силуетів сприймається як особливий конфігуративний простір, де панує розмаїття пласких людей, що виводить свідомість на культ одномірної людини. Це якраз і є художній принцип образів постнекласичного світу, коли долучення виміру часу до простору сплощує та спрощує сам принцип додавання. Принцип розширення 
простору робить його тією мембраною, яка вібрує та відштовхує в безкінечність далечини можливих просторових відносин найбільшу колись цінність - людину.

Особливий образ художнього світу, що виникає в жанрі оптичного видовища в моді, належить теж Іссею Міяке. У 1996 році картину Енгра «Джерело» митець проеціює на одяг. Подібний принт є своєрідною інсталяцією, яка потім стає модною. Візуальний світ як видовище захоплює одяг, одяг як планетарне явище, як видиво стає візіоном або зображенням у зображенні. Тобто можна стверджувати, що типологічно зберігається один варіант - простір у просторі, простір як складена або співскладена конструкція. Це або співскладеність різних мов, як у Пікассо протягом його творчості, коли він переходив з однієї мови на іншу, або культурний діалог - культурні алюзії постмодерну, коли зберігається просторовий інваріант незаспокоєного, багатоцентрового й водночас осьового простору. Постмодерн, спростивши до еклектичного симбіозу модерні витоки, відносини людини й універсуму, людини й всесвіту, створив нове видовище, видовище як заперечення, як таке просторове явище, де суб'єктом стає той, хто сам бачить світ.

Доба за добою змінює можливість людини бути, бачити, але це бачення страхітливе. Чому? Тому що людина збентежена, тому що світ все більше й більше стає катастрофічним і незрівноваженим. Таким чином, ми можемо уявити, як від класичного, посткласичного до постнекласичного простору та принципів формотворення змінюються сам $i$ парадигми бачення, але топологічні інваріанти й типологія залишається майже незмінною. Вона залишається інваріантною світовідношенню людини в просторі видива ХХ століття. Образ світу вміщується в дихотомію граничних універсалій таких як темрява і світло, а семантичні ознаки, що пов'язуються 3 добром і злом, чорним і білим, проходять крізь культуру ХХІ століття.

Все це набуває культуророзмірних i людиновимірних відзнак у просторі образу світу саме у внутрішньому просторі душі людини. У наш час саме споглядання образу світу та бачення стає самодостатнім, естетичним явищем. Воно може бути експресивним, публічним, драматичним, піднесеним. Усі відзнаки естетичної категорії видовища можуть бути характерними для бачення. Але воно може бути й антиестетичним. Це теж видовище. Це може бути видовище людини затисненої в кут, людини, яка втратила світ. Вся історія культури сповнена можливостями як гармонійного, так і деструктивного бачення.

Висновки. Отже, на тлі соціокультурних процесів останніх десятиліть чітко окреслилася необхідність пошуку нових підходів при 
дослідженні художніх явищ, особливо трансформацій образу світу на межі класичного, некласичного та постнекласичного часопростору. Глобалізація, імперативи інформатизації, плюралізму та толерантності, очищення від нашарувань констант попереднього світогляду представляються найважливішими культурними трендами сучасного світу. Вони наполегливо висувають завдання інтеграції всіх існуючих уявлень про світ задля універсалізації знання. Виключно високим інтегративним потенціалом наділено концепт «художній образ світу», релятивно сформований на базі перетворюючої функції естетичної свідомості й мистецтва некласичного часу, що в мистецтві постнекласичної доби повністю відходить від логоцентризму та міметичних форм.

1. Гуменюк Т. «Друга реальність» сучасної культури та ї̈ виміри. Погляд на вік $X X$ з початку ХХІ століття // Київське музикознавство, 2014. Вип. 48. С. 3-15.

2. Мусат Р.П. Художественная картина мира: принципы двухосновной природы // Грамота. 2015. № 9 (59). С. 115-118.

3. Стёпин В. С. Теоретическое знание. Москва : Прогресс-Традищия, 2000. 744 c.

4. Флиер А.Я. Модель культурной типологии: классическая, неклассическая и постнеклассическая культуры // Информационный гуманитарный портал «Знание. Понимание. Умение». 2016. № 1 (январь-февраль). URL: http://zpu-journal.ru/ezpu/2016/1/Flier_Cultural-Typology-Model/ [архивировано в WebCite] (dama обращения: 01.03.2018).

5. Шубина А.О. Концепть художественной картины мира //Вестник МГГУ им. М. А. Шолохова. Филологические науки. 2009. № 4. С. 94-98.

6. Ясперс К. Смысл и назначение истории. Москва : Политиздат, 1991. 527 с.

\section{References}

1. Humenyuk, T. (2014). "Second reality» of modern culture and its measurement. A look at the XX century from the beginning of the XXI century ["Druha real'nist'» suchasnoyi kul'tury ta yiyi vymiry. Pohlyad na vik XX z pochatku XXI stolittya], Kyyivs'ke muzykoznavstvo, No. 48, pp. 3-15.

2. Musat, R. (2015). Artistic picture of the world: the principles of a two-basic nature [Khudozhestvennaya kartina mira: printsipy dvukhosnovnoy prirody], Gramota, No. 9 (59), pp. 115-118.

3. Stepin, V. (2000). Theoretical knowledge [Teoreticheskoye znaniye], Moscow, ProgressTraditsiya, $744 \mathrm{p}$.

4. Flier, A. (2016). Model of cultural typology: classical, nonclassical and post-nonclassical cultures [Model' kul'turnoy tipologii: klassicheskaya, neklassicheskaya $i$ postneklassicheskaya kul'tury], Informational humanitarian portal "Znaniye. Ponimaniye. Umeniye”. No. 1 (January-February), [online] Available at: https: zpu-journal.ru/ezpu/2016/1/Flier_Cultural-Typology-Model/ [Accessed 01 march 2018].

5. Shubina, A. (2009). Concepts of the artistic picture of the world [Kontsepty khudozhestvennoy kartiny mira], Vestnik MGGU im. M. A. Sholokhova. Filologicheskiye nauki, No. 4, pp. 94-98.

6. Jaspers, K. (1991). The meaning and purpose of history [Smysl i naznacheniye istorii], Moscow, Politizdat, 527 p. 